\title{
FROM SUBDIVISION IMPROVEMENT REQUIREMENTS TO COMMUNITY BENEFIT ASSESSMENTS AND LINKAGE PAYMENTS: A BRIEF HISTORY OF LAND DEVELOPMENT EXACTIONS
}

\author{
R. MARLin SMIth*
}

\section{INTRODUCTION}

In the beginning there were only paper subdivisions. In the nineteenth century and well into the third decade of this century, land could be subdivided without constructing the public improvements that would be needed to serve the subdivided land. The subdivider needed only to prepare an accurate plat of the property to be subdivided, usually with the assistance of a surveyor, and then record it in the appropriate county office. The subdivider did not assume responsibility for constructing any of the subdivision improvements. That task was left to the municipality or to the purchasers of lots in the subdivision. Streets were laid out but, in many instances, title to the street did not pass to the municipality unless it improved the street or actual use of the street had already commenced. ${ }^{1}$

The practice of recording subdivision plats without making any provision for the construction of public improvements produced two undesirable results. First, the premature subdivision of land created an oversupply of subdivided lots. Lacking purchasers, many paper subdivisions were only partially improved or never improved at all, and they became "dead land" that impeded the normal and orderly growth of municipalities. As a consequence, new residential developments leapfrogged over such areas of dead land into unsubdivided lands lying beyond the old, moribund subdivisions. Moreover, because they remained vacant, tax delinquencies became chronic and widespread in these unimproved dead subdivisions, a

Copyright $\odot 1987$ by Law and Contemporary Problems

* This article is published posthumously. Mr. Smith was a partner at Ross \& Hardies, Chicago, Illinois.

1. American Soc'y of Planning Officials, Planning Advisory Info. Rep. No. 38, Installation of Physical Improvements as Required in Subdivision Regulations (1952) [hereinafter Installation of Physical Improvements]; Mills, The Functioning of Planned Subdivision Control, Proc. Joint Conf. on City, State \& Nat'l Plan. 65 (1935). 
condition that further discouraged and frustrated attempts to develop the land. ${ }^{2}$

Second, in addition to ad valorem tax delinquencies, the depression of the early 1930's caused widespread delinquencies in payment of special assessments that had, in some instances, been levied to construct the physical improvements in platted subdivisions. The incentive to pay such special assessments existed only when the assessed lot had been improved by construction of a residence. Special assessment liens were foreclosed, but only a fraction of the assessments due were realized upon foreclosure because of the general depreciation in land values. As a result, the municipalities that had levied the assessments did not have sufficient funds to pay either the principal or the interest on special assessment bonds as they became due, there were widespread defaults on those bonds, and some bondholders suffered heavy losses. Special assessment bonds became suspect investments, and it became increasingly difficult for municipalities to find a market for these bonds or to persuade contractors to accept them as payment for the construction of subdivision improvements. ${ }^{3}$ Not wishing to recreate the unhappy experience of the early 1930's, more and more cities sought to solve the problem by securing the construction of physical improvements in subdivisions. Many cities began requiring subdividers to become land developers. They required the developer either to construct improvements at his own expense, or post a bond or other financial guarantee with the municipality, the proceeds of which could be used to construct improvements that the subdivider failed to provide. ${ }^{4}$

By 1958 , the mandatory construction of subdivision improvements as a condition of subdivision plat approval had become the dominant method of securing such improvements. In that year, a survey conducted by the International City Managers Association of 880 cities with populations of over 10,000 revealed that 692 of the cities surveyed had subdivision regulations. Six hundred fifteen of those cities imposing regulations required the subdivider to install one or more types of physical improvements in the subdivisions they were platting. ${ }^{5}$

2. Installation of Physical Improvements, supra note 1, at 1-2; Aschman, Dead Land: Chronically Tax Delinquent Lands in Cook County, 20 LAND ECON. 40 (1946); Crane, Jr., Subdivision Regulation in Unincorporated Areas, 22 Proc. Nat'l Plan. Conf. 15 (1930); Note, An Analysis of Subdivision Control Legislation, 28 IND. L.J. 544, 545-46 (1952).

3. Bryant, Special Assessments and Special Taxing Districts, 1952 A.B.A. SEc. Mun. L. ReP. 29. The substantial discounts imposed by banks to which contractors attempted to sell the bonds made construction of public improvements by special assessment more costly because contractors took the prospective discount into account in submitting bids.

4. Installation of Physical Improvements, supra note 1, at 1-2; Mills, supra note 1, at 65.

5. International City Managers Ass'n, Municipal Yearbook 253-60 (1958); see also Tenn. State Planning Comm'n, Pub. No. 282, Subdivision Improvement Costs: Who Pays for What 9. 20 (1958); Urban Land Inst., Technical Bull. No. 27, Utilities and Facilities for New Residential. Development 11 (1955). For a contemporary description of subdivision improvement requirements, procedures, and financial guarantees, see Schultz \& Kelley, Subdivision Improvement Requirements and Guarantees: A Primer, 28 J. Urb. \& Contemp. L. 3 (1985). 
II

\section{Compulsory SUbDIVISION IMPROVEMENTS}

\section{A. On-Site Improvements}

As one would expect, the real estate community was initially reluctant to recognize either the wisdom or the constitutionality of conditioning subdivision plat approval on the installation of public improvements in the subdivision. Most courts, however, did not share the real estate community's sense of outrage at this burden, and such requirements were virtually uniformly upheld. An early Michigan decision upheld the compulsory dedication of land for subdivision streets. ${ }^{6}$ The New York Court of Appeals rejected the claim that mandatory street dedications and improvements constituted a taking of private property for public use without compensation. ${ }^{7}$ In a short period of time, numerous courts sustained requirements for the construction of various public improvements on subdivision rights of way such as sewers, ${ }^{8}$ watermains, ${ }^{9}$ sidewalks, ${ }^{10}$ curbs and gutters, ${ }^{11}$ storm drains, ${ }^{12}$ and even landscaping. ${ }^{13}$

There have been, however, occasional setbacks. A New Jersey court struck down a portion of an ordinance requiring construction of off-site watermains because no standards existed for determining whether the watermains were in fact needed by the development in question. ${ }^{14}$ The same decision, however, recognized the general authority of municipalities to require on-site watermains. ${ }^{15}$

\section{B. Off-Site Improvements}

Having waged successful combat over the question of installation of onsite subdivision improvements, municipalities turned their attention to an additional, more difficult objective: requiring the subdivider to finance the construction of off-site improvements. This requirement actually includes two somewhat different types of regulations. One is a requirement that the subdivider construct improvements not on land in the subdivision itself, but

6. Ridgefield Land Co. v. Detroit, 241 Mich. 468, 217 N.W. 58 (1928).

7. Brous v. Smith, 304 N.Y. 164, 106 N.E.2d 503 (1952).

8. E.g., Mefford v. City of Tulare, 102 Cal. App. 2d 919, 228 P.2d 847 (1951); City of Bellefontaine Neighbors v. J.J. Kelly Realty \& Bldg. Co., 460 S.W.2d 298 (Mo. Ct. App. 1970); Medine v. Burns, 29 Misc. 2d 890,208 N.Y.S.2d 12 (Sup. Ct. 1960).

9. E.g., Crownhill Homes, Inc. v. City of San Antonio, 433 S.W.2d 448 (Tex. Ct. Civ. App. 1968); Zastrow v. Village of Brown Deer, 9 Wis. 2d 100, 100 N.W.2d 359 (1960).

10. E.g., Allen v. Stockwell, 210 Mich. 488, 178 N.W. 27 (1920); City of Bellefontaine Neighbors v. J.J. Kelly Realty \& Bldg. Co., 460 S.W.2d 298 (Mo. Ct. App. 1970).

11. E.g., Petterson v. City of Naperville, 9 Ill. 2d 233, 137 N.E.2d 371 (1956).

12. E.g., Delight, Inc. v. Baltimore County, 475 F. Supp. 754 (D. Md. 1979), aff'd, 624 F.2d 12 (4th Cir. 1980).

13. E.g., Mac-Rich Realty Constr., Inc. v. Planning Bd., 4 Mass. App. Ct. 79, 341 N.E.2d 916 (1976).

14. Lake Intervale Homes, Inc. v. Township of Parsippany-Troy Hills, 28 N.J. 423, 442, 147 A.2d 28, 39 (1958).

15. Id. 
rather on land bordering on the edge of the subdivision, crossing it, or extending out from it. The other type of regulation, usually issued with respect to storm drains or water and sewer mains, requires that lines in the subdivision or those extending out from it contain sufficient excess capacity to serve other developments.

Municipalities have had more mixed success with mandatory off-site improvement requirements than with on-site improvement requirements. The California Supreme Court was one of the first courts to consider this issue in Ayres $v$. City Council, ${ }^{16}$ often considered the seminal case supporting mandatory street-dedication requirements. The real importance of Ayres, however, is not that it approved mandatory on-site dedications, but that it upheld a regulation requiring dedication of an additional right of way along an existing public street bordering on the subdivision. The approval of such a regulation is significant because it was questionable whether dedication of the additional right of way fulfilled a need created by the subdivision. ${ }^{17}$ Thus, the court approved a classic off-site requirement. Similarly, in Hudson Oil Co. v. City of Wichita, ${ }^{18}$ the Kansas Supreme Court upheld a municipal land dedication requirement. In order to receive approval of a rezoning application, the developer was required to dedicate an additional right of way that was designed to provide sufficient space for construction of a frontage road in order to prevent individual driveway access to an arterial street. The court felt that the requirement was "necessary to maintain uniformity in a service or frontage street . . ."'19

Not all challenges to mandatory off-site improvement requirements have failed. For example, the Michigan Supreme Court held that Livingston County did not have the authority to require a developer to improve an offsite road by removing a hill and regrading the road. ${ }^{20}$ In addition, the Virginia Supreme Court held that Fairfax County officials could not require a developer to pay the cost of reconstructing parts of two state secondary roads abutting the proposed development. ${ }^{21}$ In New Jersey, the state supreme court required a municipality to reimburse a developer who had contributed to the cost of an off-site drainage facility in order to receive subdivision approval, even though the drainage facility was constructed as a general improvement and no part of the cost was allocated to other properties that were specially benefited. ${ }^{22}$ Recently, the Alabama Supreme Court held that the authority of

16. 34 Cal. 2d 31, 207 P.2d 1 (1949).

17. Id. at 31,207 P.2d at 1 .

18. 193 Kan. 623, 396 P.2d 271 (1964).

19. Id. at 629,396 P.2d at 275.

20. Arrowhead Dev. Co. v. Livingston County Rd. Comm'n, 413 Mich. 505, 322 N.W.2d 702 (1982).

21. Hylton Enters. v. Board of Supervisors, 220 Va. 435, 258 S.E.2d 577 (1979). The Virginia Supreme Court has recently distinguished the Hylton decision in County Supervisors v. Sie-Gray Developers, Inc., 230 Va. 24, 334 S.E.2d 542 (1985). In Sie-Gray, the court held that a developer's voluntary agreement to make off-site improvements is enforceable. A dissenting opinion questioned just how "voluntary" the agreement was in the context of the usual development permission process. Id. at —, 334 S.E.2d at 548 (Russell, J., dissenting).

22. Divan Builders, Inc. v. Planning Bd., 66 N.J. 582, 334 A.2d 30 (1975). 
the city of Mobile over subdivisions did not permit it to require that a developer reserve a 100 -foot wide strip of land outside a proposed subdivision for a future thoroughfare. ${ }^{23}$

Other courts have adopted a middle-of-the-road approach to the question of off-site improvements. The New Hampshire Supreme Court has held that a developer can be required to improve off-site roads providing access to the development, but only to the extent of the developer's fair share of the costs. ${ }^{24}$ If those roads would serve needs beyond those generated by the subdivision, the municipality must share the cost. ${ }^{25}$ A second alternative is commonly called a "recapture agreement." These agreements, usually embodied in municipal ordinances, require the developer to advance the full amount of the construction and installation costs required to make the public improvements. ${ }^{26}$ Those costs, however, are subsequently apportioned among the various properties that benefit from the improvements. Through subdivision and tap-on fees, the municipality secures from subsequent developers the portion of the cost not attributable to the initial development. It then refunds those sums with interest to the developer that advanced the funds for construction of the improvements. ${ }^{27}$ Recapture agreements are typically recorded on county title records so that subsequent purchasers of land subject to recapture payments will take title with knowledge of the obligation.

\section{III}

\section{Challenges to Subdivision Exactions}

Challenges to subdivision exactions have centered on three principal objections: (1) that a subdivision exaction is an ultra vires requirement, that is, the municipality lacks the statutory authority to impose such an exaction; (2) that the subdivision exaction is unreasonable because it is unrelated to the provision of an improvement needed by the subdivision itself; and (3) that some municipalities' practice of requiring cash payments in lieu of land dedication is unauthorized or is, in fact, an impermissible form of taxation. Each of these objections will be examined in turn.

23. Arnett v. City of Mobile, 449 So. 2d 1222 (Ala. 1984).

24. Land/Vest Properties, Inc. v. Town of Plainfield, 117 N.H. 817, 379 A.2d 200 (1977). A similar approach to apportioning the cost of removing an off-site ledge that obstructed vision on a nearby road was taken in J.E.D. Assocs. v. Town of Atkinson, 121 N.H. 581, 432 A.2d 12 (1981).

25. 117 N.H. at 822,379 A.2d at 203 .

26. See, e.g., Ill. Rev. Stat. ch. 24, paras. 9-5-1 to 9-5-3 (1983).

Courts in numerous jurisdictions that have not adopted legislation similar to the Illinois legislation have held, however, that municipal ordinances containing recapture agreements are void as beyond the scope of the general state enabling statute. See, e.g., Kelber v. City of Upland, 155 Cal. App. 2d 631, 318 P.2d 561 (1957); Rosen v. Village of Downers Grove, 19 Ill. 2d 448, 167 N.E.2d 230 (1960); Coronado Dev. Co. v. City of McPherson, 189 Kan. 174, 368 P.2d 51 (1962); Ridgemont Dev. Co. v. City of E. Detroit, 358 Mich. 387, 100 N.W.2d 301 (1960).

27. See, e.g., Ill. Rev. Stat. ch. 24, para. 9-5-2 (1983). 


\section{A. The Ultra Vires Objection}

Absent free-wheeling home rule authority, express or implied statutory authority is crucial to the validity of an exaction. Ordinarily, whether there is specific statutory authority for a challenged requirement does not pose a significant problem. For example, in Aunt Hack Ridge Estates v. Planning Commission, ${ }^{28}$ the Connecticut Supreme Court rejected a subdivider's claim that a state statute prohibited a park dedication requirement in an eleven-lot subdivision of the lesser of 10,000 square feet or four percent of the subdivided area. ${ }^{29}$ The statute authorized promulgation of subdivision regulations that would enable the Planning Commission to "provide open spaces for parks and playgrounds when, and in places, deemed proper by the Planning Commission, which open spaces for parks and playgrounds shall be shown on the subdivision plan." 30

In some instances, however, courts have rejected a statutory interpretation that would authorize subdivision requirements. For example, the Illinois Supreme Court has held that a statute authorizing municipalities to establish reasonable standards of subdivision design including, among other things, school grounds, did not authorize a municipal ordinance requiring the dedication of land for educational purposes. ${ }^{31}$ In Kelber $v$. City of Upland, ${ }^{32}$ a California court held that a municipality had exceeded its authority by requiring payment into a general park and school fund that benefited the entire city as a condition of subdivision approval. Subsequently, however, the California Supreme Court, in Associated Home Builders v. City of Walnut Creek, ${ }^{33}$ held that later statutory amendments had conferred the necessary authority missing in the Kelber decision.

There is a similar history in both Texas and Florida. A Texas court originally held that there existed no statutory authority for Texas municipalities to require dedication of park land as a condition of subdivision approval. ${ }^{34}$ Four years later, the Texas Supreme Court restricted the earlier holding to the specific facts of the case, and concluded that, in general, Texas municipalities could require the dedication of park lands. ${ }^{35}$ Similarly, the precedential value of an early Florida decision holding that cash payments may not be exacted as a part of the subdivision approval process ${ }^{36}$ has been considerably impaired by subsequent Florida decisions in impact fee cases. ${ }^{37}$

28. 160 Conn. 109, 273 A.2d 880 (1970).

29. Id. at 111,273 A.2d at 882; see also Billings Properties, Inc. v. Yellowstone County, 144 Mont. 25, 394 P.2d 182 (1964); Jenad, Inc. v. Village of Scarsdale, 18 N.Y.2d 78, 218 N.E.2d 673, 271 N.Y.S.2d 955 (1966).

30. 160 Conn. at $111,273 \mathrm{~A} .2 \mathrm{~d}$ at 883 .

31. Rosen v. Village of Downers Grove, 19 Ill. 2d 448, 167 N.E.2d 230 (1960).

32. 155 Cal. App. 2d 631, 318 P.2d 561 (1957).

33. 4 Cal. 3d 633, 484 P.2d 606, 94 Cal. Rptr. 630, appeal dismissed, 404 U.S. 878 (1971).

34. Berg Dev. Co. v. City of Missouri City, 603 S.W.2d 273 (Tex. Ct. Civ. App. 1980).

35. City of College Station v. Turtle Rock Corp., 680 S.W.2d 802 (Tex. 1984).

36. Admiral Dev. Corp. v. City of Maitland, 267 So. 2d 860 (Fla. Dist. Ct. App. 1972).

37. See, e.g., Hollywood, Inc. v. Broward County, 431 So. 2d 606 (Fla. Dist. Ct. App. 1983); Broward County v. Janis Dev. Corp., 311 So. 2d 371 (Fla. Dist. Ct. App. 1975). 


\section{B. The Reasonableness Tests}

The constitutionality of state laws authorizing local governments to require land dedication as a condition of subdivision approval have been uniformly upheld against challenges that they deprive the property owner of due process. ${ }^{38}$ In general, the rationale for these decisions is that the state laws are reasonably related to the achievement of legitimate governmental objectives founded in the public welfare and are therefore within the police power of the state. ${ }^{39}$ -

The principal constitutional dispute has revolved around the question whether there is a reasonable relationship between the exaction requirement and achievement of a proper public purpose. Specifically, the battle has been conducted over whether there must be a direct and demonstrable relationship between the exaction and the needs of the subdivision development, or whether a looser standard would suffice. Most jurisdictions have opted for the looser standard that there be a rational or reasonable relationship between the exaction and needs created by the development. ${ }^{40}$

In Collis $v$. City of Bloomington, ${ }^{41}$ the Minnesota Supreme Court explained the rationale for its approval of that state's version of the reasonable relationship test:

While in general subdivision regulations are a valid exercise of the police power, made necessary by the problems subdivisions create-i.e., greater needs for municipal services and facilities - the possibility of arbitrariness and unfairness in their application is nonetheless substantial: A municipality could use dedication regulations to exact land or fees from a subdivider far out of proportion to the needs created by this subdivision in order to avoid imposing the burden of paying for additional services on all citizens via taxation. To tolerate this situation would be to allow an otherwise acceptable exercise of police power to become grand theft. But the enabling statute here prevents this from occurring by authorizing dedication of only a 'reasonable portion' of land for the purposes stated. We therefore uphold the statute as constitutional. A 'reasonable portion' is construed to mean that portion of land which the evidence reasonably establishes the municipality will need to acquire for the purposes stated as a result of approval of the subdivision. This is, of necessity, a factsand-circumstances test, but it is the only kind of test that will consider the myriad of factors which may bear on a municipality's needs for certain kinds of facilities and the relationship of a particular subdivision to those needs. ${ }^{42}$

38. For a more extended discussion of the constitutional issue, see Hagman, Exactions, liser Fees and Assessments: What Are the Limits?, in Zoning and Planning Law Handbook 45 (F. Strom ed. 1983); Heyman \& Gilhool, The Constitutionality of Imposing Increasing Community Costs on Neu Suburban Residents through Subdivision Exactions, 73 YALE L.J. 1119 (1964); Johnston, Constitutionality of Subdivision Control Exactions: The Quest for a Rationale, 52 CoRnell L.Q. 871 (1962).

39. Associated Home Builders v. City of Walnut Creek, 4 Cal. 3d 633, 484 P.2d 606, 94 Cal. Rptr. 630, appeal dismissed, 404 U.S. 878 (1971); Aunt Hack Ridge Estates, Inc. v. Planning Comm'n, 160 Conn. 109, 273 A.2d 880 (1970); Billings Properties, Inc. v. Yellowstone County, 144 Mont. 25 , 394 P.2d 182 (1964); Jenad, Inc. v. Village of Scarsdale, 18 N.Y.2d 78, 218 N.E.2d 673, 27I N.Y.S.2d 955 (1966); Frank Ansuini, Inc. v. Cranston, 107 R.I. 63, 264 A.2d 910 (1970).

40. See, e.g., Home Builders Ass'n v. City of Kansas City, 555 S.W.2d 832 (Mo. 1977); Jenad, Inc. v. Village of Scarsdale, 18 N.Y.2d 78, 218 N.E.2d 673, 271 N.Y.S.2d 955 (1966); Call v. City of W. Jordan, 606 P.2d 217,220 (Utah 1979); Jordan v. Village of Menomonee Falls, 28 Wis. 2d 608, 137 N.W.2d 442 (1965), appeal dismissed, 385 U.S. 4 (1966).

41. 310 Minn. 5, 246 N.W.2d 19 (1976).

42. Id. at 17,246 N.W.2d at 26 . 
The California Supreme Court's Walnut Creek decision ${ }^{43}$ provides the leading explanation of the rationale behind the reasonable relationship test. The court said:

We see no persuasive reason in the face of these urgent needs caused by present and anticipated future population growth on the one hand and the disappearance of open land on the other to hold that a statute requiring the dedication of land by a subdivider may be justified only upon the ground that the particular subdivider upon whom an exaction has been imposed will, solely by the development of his subdivision, increase the need for recreational facilities to such an extent that additional land for such facilities will be required. ${ }^{44}$

Therefore, the court held that "the amount and location of land or fees shall bear a reasonable relationship to the use of the facilities by the future inhabitants of the subdivision." 45

The reasonableness of the relationship required by the Walnut Creek decision is very generously weighted in favor of the municipality by the California courts. In Grupe v. California Coastal Commission, ${ }^{46}$ a California court upheld a condition imposed in a new development permit requiring the dedication of two-thirds of a parcel for an easement that would provide access to a beach on the property. The lot owner had requested a building permit for a single-family home on a 15,200 square foot beachfront lot. The permit was conditioned on confinement of construction to 5,000 square feet and dedication of between 8,000 and 10,000 square feet as a lateral easement (that is, parallel to the shoreline) for public access and passive recreational use. Already developed properties surrounding the land at issue were not burdened with similar easements. Therefore, the land would not be accessible from anywhere except the shoreline below the high tide mark. ${ }^{47}$ Moreover, the easement did not provide access to the beach from a public road because it ran along the coast. The property owner claimed that the dedication was not reasonably related to needs that the construction of one residence created. Nevertheless, the court upheld the mandatory dedication, reasoning that the condition requiring beach access need not benefit the

43. 4 Cal. 3d 633, 484 P.2d 606, 94 Cal. Rptr. 630, appeal dismissed, 404 U.S. 878 (1971). For a survey of exaction requirements focusing on California law, see D. Curtin, Jr., Dedications, Exactions, and In Lieu Fees As a Land Use Planning Tool (Oct. 1985) (unpublished paper presented at the annual conference of the National Institute of Municipal Law Officers, Philadelphia, Pa.). Mr. Curtin was counsel for the municipality in the Walnut Creek case.

44. 4 Cal. $3 \mathrm{~d}$ at $639-40,484$ P.2d at 611,94 Cal. Rptr, at 635.

45. Id. at 640,484 P.2d at 612,94 Cal. Rptr. at 636 .

46. 166 Cal. App. 3d 148, 212 Cal. Rptr. 578 (1985). For another decision upholding mandatory beach access exactions, see Georgia-Pacific Corp. v. California Coastal Comm 'n, 132 Cal. App. 3d 678, 183 Cal. Rptr. 395 (1982) (upholding exaction but disapproving mandatory lateral and vertical access easements on noncontiguous parcel); see also Sea Ranch Ass'n v. California Coastal Comm'n. 527 F. Supp. 390 (N.D. Cal.), vacated and remanded. 454 U.S. 1070 (1981), dismissed as mool on remand. 552 F. Supp. 241 (N.D. Cal. 1982). By the time of the last decision in Sea Ranch, the plaintifl had already accepted the benefit of state legislation that provided compensation of $\$ 500,000$ for granting the public access sought by the Coastal Commission.

47. 166 Cal. App. 3d at 156, 212 Cal. Rptr. at 581 . 
proposed development. Instead, only an "indirect relationship" between the exaction and a need attributable to development is required. It stated:

Respondent's beach front home is one more brick in the wall separating the People of California from the state's tidelands. Although respondent's home alone has not created the need for access to the tidelands fronting his property, it is one small project among a myriad of others which together do severely limit public access to the tidelands and beaches of this state, and therefore collectively create a need for public access. Thus, the condition exacted to facilitate access is related to a need to which respondent's project contributes, even though, standing alone, it has not created the need for access. ${ }^{48}$

The Grupe decision adopted a very generous definition of the reasonable relationship required between an exaction and a development-generated need. The decision effectively gives municipalities carte blanche to impose exactions. The reason is that the construction of the residence proposed in Grupe could not, except as a matter of abstract theory, have actually created a need for an easement that granted beach access when the easement did not even provide direct access to the beach. At this level, exactions become judicially sanctioned governmental extortion, limited only by the taking rule that regulations may not deprive property of substantially all economic use.

In contrast with California courts, the Illinois courts take a very strict view of the relationship that must exist between the exaction and the needs of the subdivision. In Pioneer Trust and Savings Bank $v$. Village of Mount Prospect, the Illinois Supreme Court held that the exaction must be "specifically and uniquely attributable" to the needs of the development:49

\footnotetext{
If the requirement is within the statutory grant of power to the municipality and if the burden cast upon the subdivider is specifically and uniquely attributable to his activity, then the [dedication] requirement is permissible; if not, it is forbidden and amounts to a confiscation of private property in contravention of the constitutional prohibitions rather than reasonable regulation under the police power. ${ }^{50}$
}

Recently, the Illinois Supreme Court affirmed the specifically and uniquely attributable test in a decision in which the court stated that it will allow cash payments in lieu of land dedication if the Pioneer Trust standard is satisfied. ${ }^{51}$

A Florida court has criticized the reasonable relationship test as giving local governments "almost unlimited discretion" and has criticized the strictly and uniquely attributable test for shifting the burden of proof to the municipality. ${ }^{52}$ It has instead attempted to steer a middle course between those two positions by applying a "rational nexus" test that balances the prospective needs of the community against the property rights of the developer. The court's reasoning is that subdividing land is ordinarily a

48. Id. at 167,212 Cal. Rptr. at $589-90$ (citations and footnote omitted).

49. 22 Ill. 2d 375, 380, 176 N.E.2d 799, 802 (1961).

50. Id.

51. Krughoff v. City of Naperville, 41 Ill. App. 3d 334, 354 N.E.2d 489 (1976), aff'd, 68 Ill. 2d 352, 369 N.E.2d 892 (1977). The only other state that has adopted a rule similar to the Illinois standard is Rhode Island. See Frank Ansuini, Inc. v. City of Cranston, 107 R.I. 63, 264 A.2d 910 (1970).

52. Wald Corp. v. Metropolitan Dade County, 338 So. 2d 863 (Fla. Dist. Ct. App. 1976), cert. denied, 348 So. 2d 955 (1977). 
profitmaking business and, for that purpose, it is appropriate to distinguish between individual property owners and subdividers whose lots would become more attractive by imposing conditions that would benefit potential purchasers. ${ }^{53}$

There are limits on the subdivision exaction requirements that courts will tolerate. Some municipalities have pushed the courts to these limits. A New York court struck down as an unreasonable municipal exaction a mandatory dedication of shorefront land that would have diminished by $\$ 90,000$ the value of land costing $\$ 208,000.54$ The refusal of a different New York municipality to approve a subdivision plat on the ground that the official map showed the entire proposed subdivision as a school recreation site was also invalidated. ${ }^{55}$ An Ohio court held that a municipality could not require dedication of a strip of land that would widen a main thoroughfare $700 \mathrm{feet}$ away from the proposed subdivision. ${ }^{56}$ Additionally, a New Jersey court held that a municipality could not require a developer to pay its Board of Education to finance school construction costs. The court reasoned that the municipality had no right to refuse approval of the project simply because its school system would be unable to absorb the increased number of students or because taxes would have to be increased. ${ }^{57}$

\section{Cash Payments In Lieu of Land Dedication}

Frequently, the amount of land obtainable through a dedication would be too small or too poorly placed to be useful to the public. On the theory that each subdivision ought to pay its fair share of the cost of providing recreational and school lands, however, many municipalities have adopted the practice of requiring a cash payment in lieu of the land dedication in order to furnish funds for subsequent acquisition of larger parcels of land. The early decisions addressing the cash-in-lieu payments issue struck down such requirements, commonly on the ground that there was no statutory authority for substituting cash payments for dedications. ${ }^{58}$ Recently, however, the validity of cash-in-lieu payments has been sustained by the courts. For example, the Walnut Creek court upheld such payments. ${ }^{59}$ In reaching its decision, the court rejected a claim that cash-in-lieu payments constituted a

53. Id. at 868 .

54. East Neck Estates, Ltd. v. Luchsinger, 61 Misc. 2d 619, 305 N.Y.S.2d 922 (Sup. Ct. 1969).

55. Kessler v. Town of Shelter Island Planning Bd., 40 A.D.2d 1005, 338 N.Y.S.2d 778 (1972).

56. McKain v. Toledo City Plan Comm'n, 26 Ohio App. 2d 171, 270 N.E.2d 370 (1971)

57. Midtown Properties, Inc. v. Township of Madison, 68 N.J. Super. 197, 172 A.2d 40 (Law Div. 1961), aff'd, 78 N.J. Super. 471,189 A.2d 226 (App. Div. 1963); see also West Park Ave., Inc. v. Township of Ocean, 48 N.J. 122, 224 A.2d 1 (1966) (holding that a municipality could not require payments of $\$ 300$ per house to Board of Education as condition for issuance of certificates of occupancy).

58. See, e.g., Rosen v. Village of Downers Grove, 19 Ill. 2d 448, 167 N.E.2d 230 (1960); Coronado Dev. Co. v. City of McPherson, 189 Kan. 174, 368 P.2d 51 (1962); Haugen v. Gleason, 226 Or. 99, 359 P.2d 108 (1961).

59. Associated Home Builders v. City of Walnut Creek, 4 Cal. 3d 633, 642, 484 P.2d 606, 61314, 94 Cal. Rptr. 630, 637, appeal dismissed, 404 U.S. 878 (1971). For a discussion of the I'almut Crepk decision, see supra text accompanying note 43. 
double tax because the purchase price of new resident homes would include the amount of the in-lieu payment as well as subsequent property taxes for development and maintenance of open areas acquired. 60 In Jordan v. Village of Menomonee Falls, ${ }^{61}$ the Wisconsin Supreme Court upheld an ordinance requiring a subdivider to pay $\$ 200$ per lot instead of dedicating land at that value for school, park, or recreational needs. The Jordan court determined that the statute authorized the municipality to require such payments when the Planning Commission determined that dedication of land for those purposes was unfeasible. ${ }^{62} \mathrm{~A}$ Utah court upheld an ordinance requiring the developer to pay the cash equivalent of seven percent of the subdivided land for flood control and recreational purposes. ${ }^{63}$ Additionally, the Illinois Supreme Court limited its earlier Rosen decision to its facts and upheld cash payments in lieu of land dedication. 64

There remains a further pitfall. If not carefully drafted, a court may determine that a cash-in-lieu payment is a special tax violating the uniform taxation requirement. Moreover, if the cash-in-lieu payment is characterized as a tax, it may be invalid for want of specific statutory authority. ${ }^{65}$ An Oregon court held that a cash-in-lieu payment was in fact an unauthorized tax because the payments were to become part of the public funds of the county and used either by the county or the school district for land acquisition. Furthermore, there was no limitation on the uses of these funds to ensure that the money collected would be used to directly benefit subdivisions regulated. ${ }^{6}$ A Santa Fe, New Mexico ordinance that required payment of a $\$ 50$ per lot fee into a public facilities fund imposed in connection with subdivision plat approval was also struck down as an unauthorized city tax. ${ }^{67}$ One California court, however, recently held that a dedication or cash-in-lieu

60. Id. at 642, 484 P.2d at 613-14, 94 Cal. Rptr. at 637-38.

61. 28 Wis. 2 d 608,137 N.W.2d 442 (1965).

62. Id. at $620-21,137$ N.W.2d at 449 .

63. Call v. City of W. Jordan, 606 P.2d 217 (Utah 1979); see also Jenad, Inc. v. Village of Scarsdale, 18 N.Y.2d 78, 218 N.E.2d 673, 271 N.Y.S.2d 955 (1966).

64. Krughoff v. City of Naperville, 4 Ill. 2d 334, 54 N.E.2d 489 (1976), aff'd, 68 Ill. 2d 352, 369 N.E.2d 892 (1977); cf. Board of Educ. v. Surety Devs., Inc., 63 Ill. 2d 193, 347 N.E.2d 149 (1975) (enforcing an agreement to make cash contributions for school construction as condition to obtaining special use permit for subdivision sewage treatment plant). In Plote, Inc. v. Minnesota Alden Co., 96 Ill. App. 3d 1001, 422 N.E.2d 231 (1981), an Illinois appellate court stated that "the Illinois Supreme Court is currently tending toward a more liberal interpretation of the validity of exaction ordinances while maintaining the requirements of proportionality and specific attributability." Id. at 1006, 422 N.E.2d at 235-36. The appellate court also emphasized, however, that the standard was stringent, stating: "the test in Illinois is more demanding than a cursory search for some connection, however tenuous, between the municipality's exaction and the public welfare." Id. The court hinted that it would have invalidated a $\$ 100$ per dwelling unit exaction for a community cultural center had the plaintiff developer not been estopped from challenging the exaction ordinance.

65. See, e.g., City of Montgomery v. Crossroads Land Co., 355 So. 2d 363 (Ala. 1978).

66. Haugen v. Gleason, 226 Or. 99, 105, 359 P.2d 108, 111 (1961).

67. Sanchez v. City of Santa Fe, 82 N.M. 322, 481 P.2d 401 (1971); $c$. Lafferty v. Payson City, 642 P.2d 376, 378 (Utah 1982) (building permit impact fee of $\$ 1,000$ per dwelling unit deposited in general fund was really illegal tax); Hillis Homes, Inc. v. Snohomish County, 97 Wash. 2d 804,650 P.2d 193 (1982) ( $\$ 250$ per-lot fee for past acquisition was unauthorized tax) (superseded by $W_{A S H}$ Rev. Code. AnN. $\$ 82.02 .020$ (Supp. 1987)). 
requirement is not a special tax requiring two-thirds referendum approval under Proposition 13.68

\section{IV}

\section{The Florida Impact Fee Cases}

The general success of municipalities in sustaining provisions requiring land dedication or cash payments in lieu thereof has emboldened them to go even further by dropping the land dedication requirement altogether and simply imposing a fee on land development for construction of public improvements. These exactions are called "impact fees" and they are justifed on the theory that it is possible to allocate to each development its proportionate share of the future cost of providing public services such as parks and highway improvements. 69

To date, much of the litigation over impact fees has occurred in Florida. The initial effort to impose impact fees in Florida fared poorly in Broward County $v$. Janis Development. ${ }^{70}$ In that case, the court held that a land use fee, collected to fund the cost of constructing or improving roads, streets, highways, and bridges serving the vicinity of the development, was not an appropriate exercise of regulatory authority. Instead, it constituted an invalid form of taxation because it did not specify how or when the money would be spent. ${ }^{71}$

The case that set the stage in Florida for the subsequent impact fee decisions was Contractors $\mathcal{E}^{2}$ Builders Association v. City of Dunedin. ${ }^{72}$ In that case, a Florida appellate court upheld the imposition of a fee on the construction of homes and buildings levied at the time of connection to municipal water and sewage systems. The designation of the connection fees as payment for the capital costs of expanding the city's water and sewer system was crucial to the validity of the Dunedin ordinance. ${ }^{73}$

The next impact fee case to reach a Florida court was Hollywood, Inc. $v$. Broward County. ${ }^{74}$ A Broward County ordinance required, as a condition of plat approval, the dedication of land or a fee payment in order to assist the county in acquiring and developing county level parks. Under the Broward ordinance, the subdivider had three alternatives. He could: (1) dedicate three acres of land for every 1,000 residents of the proposed subdivision; (2) pay an

68. Trent Meredith, Inc. v. City of Oxnard, 114 Cal. App. 3d 317, 170 Cal. Rptr. 685 (1981).

69. For a fuller discussion of impact fees, see Juergensmeyer \& Blake, Impact Fees: An Ansuer to Local Government's Capilal Funding Dilemma, 9 FLA. ST. U.L. REv. 415 (1981).

70. 311 So. 2d 371 (Fla. Dist. Ct. App. 1975).

71. Id. at 376 .

72. 358 So. 2d 846 (Fla. Dist. Ct. App. 1978), cert. denied, 370 So. 2d 458, cert. denied. 444 U.S. $867(1979)$

73. Id. at 847-48. The Florida Supreme Court had previously invalidated the Dunedin ordinance because it had placed insufficient restrictions on the use of the money collected. Contractors \& Builders Ass'n v. City of Dunedin, 329 So. 2d 314 (Fla. 1976). The later decision upheld the ordinance after it had been amended to provide for the earmarking of funds. 358 So. $2 \mathrm{~d}$ at 846, 848 (Fla. Dist. Ct. App. 1978), cert. denied, 370 So. 2d 458, cert. denied, 444 U.S. 867 (1979).

74. 431 So. 2d 606 (Fla. Dist. Ct. App.), cert. denied, 440 So. 2 d 352 (1983). 
amount of money equivalent to the value of land that would have been dedicated; or (3) pay the impact fee set by a schedule in the ordinance. ${ }^{75}$ The court first held that the required dedication of three acres of land for every 1,000 residents was not unreasonably high. Indeed, the court felt the standard might even be low. It also noted that the county had employed various mechanisms designed to meet the needs of the current population for county level parks, including a $\$ 73$ million bond issue. The county's evidence also demonstrated that growth generated by new subdivisions would require the county to acquire and develop new lands in order to maintain its three acres per 1,000 residents standard. ${ }^{76}$ Moreover, the Broward ordinance required collected funds to be expended

within a reasonable period of time, for the purpose of acquiring and developing land necessary to meet the need for county level parks created by the development in order to provide a system of county level parks which will be available to and substantially benefit the residents of the platted area. ${ }^{77}$

The ordinance limited use of the funds to acquiring and developing new park land within fifteen miles of the platted land. The court held that requirements such as those in the Broward ordinance are permissible as long as they "offset needs sufficiently attributable to the subdivision and so long as the funds collected are sufficiently earmarked for the substantial benefit of the subdivision residents."78 The court established a two-part test that places the burden of proof on the county. The local government must first demonstrate a reasonable connection, or rational nexus, between the need for additional facilities and growth in population generated by the subdivision. Second, it must show a rational nexus between the expenditure of the funds collected and the benefits accruing to the subdivision. To satisfy the second test, the ordinance must specifically earmark the funds collected for use in acquiring capital facilities to benefit the new residents. ${ }^{79}$ The Broward County ordinance passed muster because the county demonstrated that the three acres per 1,000 residents standard was reasonable, and because the fifteenmile provision and the earmarking of funds ensured that the sums collected would be used to acquire capital facilities for the benefit of new residents. ${ }^{80}$

At issue in the second Florida impact fee case, Home Builders E Contractors Association v. Board of County Commissioners, ${ }^{81}$ was an impact fee established to fund the construction of roads, the need for which was generated by increased traffic from the new development. The Palm Beach County ordinance required any new land development activity that generated traffic to pay a fair share of the reasonably anticipated cost of expanding or constructing roads

75. Id. at $607-08$.

76. Id. at 612 .

77. Id.

78. Id. at 611 .

79. Id. at 611-12.

80. Id. at 612 .

81. 446 So. 2d 140 (Fla. Dist. C.. App. 1983), cent. denied, 451 So. 2d 848, appeal dismissed, 409 U.S. $976(1984)$. 
attributable to the new development. ${ }^{82}$ Utilizing a formula that took into account the cost of road construction and the number of motor vehicle trips generated by different types of land use, the ordinance required a fee of $\$ 300$ per unit for single family housing, $\$ 200$ per unit for multiple family dwellings, \$175 per unit for mobile homes, and other amounts for commercial or other development. Payment of the fee was required upon commencement of any new land development activity that would generate traffic. An unusual feature of the ordinance was that it established a trust fund for each of forty zones into which the county was divided. Funds collected from building activity in a particular zone could only be spent in that zone within six years after collection, or the money would be returned to the present owner of the property. ${ }^{83}$

The court held that although Palm Beach County was a noncharter county and thus did not have home rule authority, the county did have the power and authority to enact the ordinance as long as the exaction constituted a regulatory fee rather than a tax. ${ }^{84}$ The court rejected an argument that the ordinance was invalid on the ground that there might be some disparity between those who benefit and those who pay. It also rejected the contention that benefits accruing from roads constructed with the impact fees must inure exclusively or overwhelmingly to the subdivision residents. ${ }^{85}$ The developer also argued that the ordinance violated equal protection rights because it was arbitrary and discriminatory. The basis for this argument was that the Florida Constitution permits municipalities to opt out of application of the ordinance, and thirty-three of the thirty-seven municipalities in the county had done so. The court rejected this argument, reasoning that the constitutional guarantee of equal protection does not require territorial uniformity. ${ }^{86}$

As the court also noted, the most difficult point raised on appeal was the claim that the Palm Beach County impact fee constituted a tax rather than a regulatory fee. The court stated that the distinction between the two "almost seems to become more amorphous rather than less." 87 The court found that the ordinance was not a tax because it met the tests articulated in Dunedin and because the evidence demonstrated that the rapid rate of new development in the county required a substantial increase in the capacity of the county road system. It also found that the construction cost of those roads would far exceed the fair share of fees imposed by the ordinance, and that the formula for calculating the amount of the fee was not rigid and inflexible. Instead, the formula allowed the developer to furnish his own independent study of traffic and economic data in order to demonstrate that his share should be less than the amount set under the ordinance formula. Finally, the localization of the

\footnotetext{
82. Id. at 141 .

83. Id. at 142 .

84. Id. at $142-43$.

85. Id. at $143-44$

86. Id. at 144 .

87. Id.
} 
expenditure of funds through the zone system also served to differentiate the impact fee from a tax. ${ }^{88}$

The Florida line of cases suggests that there are five requirements for a valid impact fee ordinance. First, there must be a carefully documented estimate of the cost of acquiring and constructing new public facilities. Second, there must be a reasonable formula for determining the portion of the cost imposed on new developments, and it should appear that the local government is not attempting to thrust the entire burden of new public facilities onto new developments. Third, the funds collected must be segregated and earmarked instead of being mingled with general public funds. Fourth, the expenditure of the funds must be localized in order to increase the likelihood that residents of the new development will benefit from the facilities. Finally, there must be a time limit within which the funds can be expended and a provision for refunds if the time limit is exceeded. ${ }^{89}$ This last provision ensures that the funds will actually be spent to benefit residents of the new development.

The Wheel Traces a Full Circle: The Return of the Special Assessment, With a Difference

While Florida municipalities were experimenting with impact fees, California was reintroducing the special assessment, but with some significant differences. Laboring under the ad valorem tax limitations of Proposition $13,{ }^{90}$ California municipalities utilized the special assessment in order to raise cash for public facilities.

88. Id. at 145 .

89. In Town of Longboat Key v. Lands End, Ltd., 433 So. 2d 574 (Fla. Dist. Ct. App. 1983), a Florida appellate court held that an impact fee for preserving or acquiring parks and open spaces was an unconstitutional tax because there was no guarantee that the funds collected would actually be used to develop parks, the need for which was generated by new construction. The Florida Omnibus Growth Management Act of 1985, Fla. STAT. ANN. $\$ 380.06(15)(d)$ (West Supp. 1986), provides standards for judicial review of impact fees. The statute requires that dedications and impact fees meet three criteria. First, the need for construction of new facilities or additions to present facilities must be reasonably attributable to the proposed development subjected to the fee or dedication. Id. $\$ 380.06(15)(d)(1)$. Second, any required dedication of land or contribution of funds or public facilities must be comparable to the funds that would have to be expended or to the land or public facilities that would have to be provided by government to accommodate the impact occasioned by the development. Id. $\$ 380.06(15)(\mathrm{d})(2)$. Third, all land dedications and funds contributed must be specifically designated for, and employed in, the mitigation of impacts reasonably attributable to the proposed development. Id. $\$ 380.06(15)(\mathrm{d})(3)$.

90. Cal. Const. art. XIIIA (1978). The impact of Proposition 13 on the finances of California municipalities was documented in a series of articles in the San Francisco Chronicle from October 28 to October 31, 1985. The Chronicle charged: 
The stage was set by the decision in Solvang Municipal Improvement District $v$. Board of Supervisors, ${ }^{91}$ in which the court articulated what it considered the distinguishing features of the special assessment technique:

[A] special assessment, sometimes described as a local assessment, is a charge imposed
on particular real property for a local public improvement of direct benefit to that
property, as for example a street improvement, lighting improvement, irrigation
improvement, sewer connection, drainage improvement, or food control
improvement. The rationale of special assessment is that the assessed property has
received a special benefit over and above that received by the general public. The
general public should not be required to pay for special benefits for the few, and the
few specially benefited should not be subsidized by the general public. . . Although a
special assessment is imposed through the same mechanism used to finance the cost of
local government, in reality it is a compulsory charge to recoup the cost of a public
improvement made for the special benefit of particular property. It has been said that,
strictly speaking, a special assessment is not a tax at all, but a benefit to specific real
property financed through use of public credit. . .
...
and In sum, a special assessment is a charge levied against real property particularly
improvectly benefited by a local improvement in order to pay the cost of that
improvent. 92

The Solvang decision enabled municipalities to finance public improvements with special assessments free of the Proposition 13 limitation on ad valorem real property taxes by sweeping into the assessment category any charge levied against real property that could be benefited by some public improvement.

The City of San Diego was one of the first municipalities to capitalize on the opportunities made available by the Solvang decision. By ordinance, it required public facilities in parts of the community designated as "planned urbanizing areas" to be financed by "special assessment proceedings, considerations from developers, the City's General Fund or some combination thereof."'93 Public improvements included water mains, utilities, sewers, drainage systems, streets and sidewalks, parks, transit and transportation, libraries, fire stations, school buildings, police stations, and presumably anything else considered by municipalities. The ordinance also designated a "fixed benefit area" (FBA) for proposed developments, and

Although the prevailing wisdom insists that the measure's principal legacy has been a windfall saving for property owners and a simpler, fairer tax code, there is also a less appealing heritage.

It can be found in crumbling roads and worn-out bridges, in crowded classrooms and a soaring high school drop-out rate....

Perhaps most egregiously, it is apparent in the existence of 'tax-rich' and 'tax poor' counties, cities and citizens-where new inequities and hardships exact their greatest toll from those who can least afford it ....

In education, public works and the less tangible but no less substantive issues of fairness, Proposition 13's effect has been both arguably harmful and increasingly apparent.

San Francisco Chronicle, Oct. 28, 1985, at 1, col. 1.

91. 112 Cal. App. 3d 545, 169 Cal. Rptr. 391 (1980).

92. Id. at 552-54, 169 Cal. Rptr. at 395-96.

93. San Diego, Cal., Mun. Code $\$ 61.2200$ (e) (1980). Application of the ordinance is discussed at length in J.W. Jones Cos. v. City of San Diego, 157 Cal. App. 3d 745, 749, 203 Cal. Rptr. 580, 583 (1984). 
provided for allocation of benefit assessments to each undeveloped parcel in the FBA. These assessments would become a lien on undeveloped parcels, and would have to be paid when a building permit was issued or when the capital improvements program for an area called for commencement of the particular public facilities project. ${ }^{94}$ Presumably, deferred assessments would affect only those lands for which no building permit had yet been sought. As applied, the ordinance permitted protests and hearings with respect to the benefit assessments. ${ }^{95}$

There are several novel concepts in the San Diego FBA scheme. First, benefit assessments have traditionally been used for public improvements such as streets, water mains, and sewers. By utilizing benefit assessments to fund transit systems and fire stations, the FBA scheme extends the use of benefit assessments to those public facilities traditionally financed out of general revenues. The FBA scheme proceeds on the assumption that it is possible to allocate to each developer his proportionate share of providing such facilities. Second, the fixed benefit assessment is payable in one lump sum at the time the building permit is issued or, if the improvement has not yet commenced, at the time of commencement. ${ }^{96}$ The other remarkable feature of the fixed benefit assessment is that it potentially imposes double payments on the developer by exposing him to both traditional forms of subdivision exactions under the Walnut Creek rule ${ }^{97}$ as well as a second round of payments at the time the fixed benefit assessment becomes due. This innovative tour de force effectively shifts the burden of providing public facilities largely to newcomers because the cost of these facilities is reflected in the price of new housing. This burden shifting is also reflected in Proposition 13, which allows only very small annual increments in ad valorem real property taxation. Upon the sale of property, however, Proposition 13 permits the assessment valuation, and thus the amount of ad valorem taxes, to rise to the price at which the property is sold. ${ }^{98}$ Under such a system, the new purchaser will pay significantly more than the present owner.

In J.W. Jones Companies v. City of San Diego, ${ }^{99}$ a California appellate court held that the fixed benefit assessment technique was not a tax that required voter approval under Proposition 13.100 The J.W. Jones court used the Solvang decision ${ }^{101}$ as the starting point of its analysis. The fixed benefit assessment looked, at least superficially, like a special tax because the funds were

94. San Diego, Cal., Mun. Code $\S \S 661.2209-2210$ (1980); see also 157 Cal. App. 3d at 749, 203 Cal. Rptr. at 583.

95. San Diego, Cal., Mun. Code $\S \S 61.2206-.2207$ (1980); see also 157 Cal. App. 3d at 750, 203 Cal. Rptr. at 583.

96. San Diego, Cal., Mun. Code $\S 61.2210$ (1980); see also 157 Cal. App. 3d at 749-50, 203 Cal. Rptr. at 583.

97. 4 Cal. 3d 633, 484 P.2d 606, 94 Cal. Rptr. 630, appeal dismissed, 404 U.S. 878 (1971). See supra text accompanying notes 43-45 for a discussion of the Walnut Creek decision.

98. Cal. Const. art. XIIIA (1978). Proposition 13 is discussed in J.W. Jones, 157 Cal. App. $3 \mathrm{~d}$ at 751, 203 Cal. Rptr. at 584.

99. 157 Cal. App. 3d 745, 203 Cal. Rptr. 580 (1984).

100. Id. at 758,203 Cal. Rptr. at 589.

101. See supra text accompanying notes 91-92 for a discussion of the Solvang decision. 
collected and earmarked for one or more special purposes and were deposited in the city's general fund. The court acknowledged that the fixed benefit assessment had its roots in state legislation generally providing for public facility financing by apportioning the cost among properties specially benefited by the facilities. The court, however, concluded:

Substantively, the ordinance and the FBA are but distant cousins to those familiar public work financing arrangements which contemplate the fixing of times for the commencement and completion of the work, the award of contracts for the work, the spread of the cost of the work to property specially benefited by it and the assessment of the benefited parcels to pay the cost of the work through the issuance of bonds constituting a lien on the benefited parcel. ${ }^{102}$

The San Diego ordinance was not "clothed in this traditional attire."103 The fixed benefit assessment impressed a lien only on enclaves of undeveloped property within the area of benefit. Moreover, the assessment would not be used to fund present public facilities, but only facilities installed in the future. The cost for these future public facilities could be measured in current dollars, and this figure could be adjusted upward or downward depending upon economic conditions. Furthermore, the court acknowledged that while traditional assessments are spread on a front foot, square foot, or ad valorem basis, the fixed benefit assessment used none of those techniques. Instead, the assessment was apportioned "according to the number of 'net equivalent dwelling units' attributable to each parcel at its highest potential development under current zoning."'104

The San Diego formula did not take into account the location of an assessed parcel with respect to any particular development. Nevertheless, the court declined to find that the fixed benefit assessment was a special tax. Its reasoning, however, was a bit weak. The court relied on the fact that the assessments did not exceed the cost of improvements, were not made on an ad valorem basis, and did not result in personal liability. The court did not hold that contiguity was necessary in order to confer a benefit since, in levying the assessment, the city had considered the proximity of the parcels to the public facilities. The court determined that the plaintiff had failed to establish an absence of benefit and that the city's determination of benefit was conclusive. ${ }^{105}$

The J.W. Jones court dismissed the objection that developed properties were excluded from the fixed benefit assessment because they were already served by adequate public facilities and because the owners of the developed properties had not initiated the fixed benefit assessment proceedings. The court acknowledged that already developed parcels might derive some incidental benefit from the new facilities, but it "perceive[d] no discriminatory classification between developed and undeveloped properties." 106

102. 157 Cal. App. 3d at 755, 203 Cal. Rptr. at 587.

103. Id.

104. Id.

105. Id. at 756, 203 Cal. Rptr. at 588.

106. Id. at 757, 203 Cal. Rptr. at 589. 
The court also reversed the trial court's determination that each of the twenty-five separate improvements scheduled for construction in the fixed benefit area between 1981 and 1990 should be separately measured to determine the extent of the benefit conferred upon undeveloped parcels by each of those improvements. The court held that "the aggregation of all the improvements in the FBA and the spread of their costs to the undeveloped parcels in the area of benefit was proper." 107 The court noted that a "piecemeal approach" would defeat the city's general policies for development as set out in its community plan. Whether the assessment would exceed the benefit to any particular parcel apparently did not concern the court. ${ }^{108}$

In effect, the $J . W$. Jones court decided that precedent was not as important as municipal financial flexibility. In a somewhat lyrical passage, it stated:

In sum, the ordinance is the key to implementing San Diego's controlled growth concept as formalized by the general plan and community plan. The narrow strictures of general law concepts of financing public facilities as embedded in acts such as the Improvement Act of 1911 or the Municipal Improvement Act of 1913 do not accommodate the dynamics of explosive growth in sunbelt cities. The undeveloped perimeters of urban centers require to be controlled in their growth not on a street by street basis looking to adjacent properties to bear improvement costs, but from the perspective of future communities planned to be complete in themselves. The vision of San Diego's future as sketched in the general plan is attainable only through the comprehensive financing scheme contemplated by the FBA. We view the precedents of yesterday's case law, not as barriers to growth, but as the guidelines to accomplish the needs of tomorrow. We hold the ordinance as applied here is a valid exercise of San Diego's power to require undeveloped land to bear the costs of the public facilities necessary for the health and welfare of the future residents of North University City. ${ }^{109}$

The success of the $J . W$. Jones decision in shifting the cost of public facilities from the general public to newcomers alone is evident in the allocation of costs associated with the fixed benefit area in the case itself. The total cost of public facilities allocated to the North University City FBA was set at $\$ 54,776,747$. Of that amount, $\$ 25,763,289$ would be paid by developers as traditional subdivision exactions. Another $\$ 26,852,923$ would be paid by the owners of undeveloped parcels through the fixed benefit assessment when they secured building permits. Only $\$ 1,802,937$ would be paid out of the city's general revenues, and the balance of $\$ 357,598$ would come from unidentified other sources. ${ }^{110}$ Thus, the developers and landowners (who, in the case of most multilot residential developments, are one and the same) would pay $96 \%$ of the cost of providing public facilities for the fixed benefit area. For San Diego municipal finance officers and elected officials, the developers' absorption of such a high percentage of the total cost of providing public facilities is a very exciting prospect. And, by the time this article is published, the idea will have surely spread to other California municipalities.

\footnotetext{
107. Id.

108. Id

109. Id. at 757-58, 203 Cal. Rptr. at 589.

110. Id. at 750, 203 Cal. Rptr. at 583.
} 
Indeed, it seems that word of such a scheme spread even before its validity was decided. City attorneys of San Jose, Atascadero, Long Beach, Los Angeles, Monterey, Palm Springs, Pasadena, San Francisco, Santa Barbara, and Stockton all joined as amici curiae in the case, exhibiting the intense interest of other municipalities in the outcome of the case. ${ }^{111}$

The revival of the special assessment in its modern form has potential problems. It is possible that the assessment levied on a particular parcel will exceed the benefit conferred on the property. If it does, to the extent of the excess, the assessment is a taking of private property in violation of the fifth and fourteenth amendments. ${ }^{112}$ Moreover, to provide a forum for this type of complaint, the municipality will usually hold a public hearing. Some states further require judicial confirmation of the allocation, and judicial review of a claim that a particular assessment constitutes a taking is always available. Prolonged public hearings and the judicial review processes could thus render the scheme administratively unworkable.

Not all state courts have been as tolerant of the reintroduction of special assessments as have the California courts. In Montgomery County v. Schultze, ${ }^{113}$ a Maryland appellate court blocked the county's effort to shift onto abutting property owners the entire cost of constructing a cross-county connector road that would primarily serve the general public's transportation needs. The court held that in order to levy a special benefit assessment against properties adjoining a road there must be: (1) a reasonable relationship between the actual enhancement in value of the abutting property and the amount of the assessment; and (2) an apportionment of the cost between general public benefit and private special benefit. In this case, the assessment failed to reflect apportionment of the cost between public and private benefit and therefore lacked a demonstrable relationship between the assessment and some private benefit. ${ }^{114}$ It is not likely that the San Diego fixed benefit assessment would survive this type of analysis.

It remains to be seen whether the fixed benefit assessment will really produce funds for the construction of public facilities or simply chill new development. It is clear, however, that to the extent that developers in California are required to shoulder the financial burden cities are thrusting upon them, they will ultimately pass that burden on to newcomers in the form of increased housing costs. The fixed benefit assessment also has the effect of exempting those who currently reside in the city from sharing the cost of the benefit, thereby increasing prices in the already inflated residential property market in California. ${ }^{115}$

111. Id. at 747, 203 Cal. Rptr. at 581.

112. See, e.g., City of Treasure Island v. Strong, 215 So. 2d 473, 476 (Fla. 1968).

113. 302 Md. 481, 489 A.2d 16 (Ct. App. 1985).

114. Id. at $490,489 \mathrm{~A} .2 \mathrm{~d}$ at $20-21$.

115. The costs of complying with California's environmental review and environmental impact mitigation requirements have already made a substantial contribution to increased housing costs in that state. See B. Frieden, The Environmental. Protection Hustle 52-59 (1979). 


\section{Linkage: Impact Fees as a Tool of Social Policy}

The most recent development in the field of municipal financial exactions has been the extension of the impact fee concept. Formerly, impact fees were used to finance various types of public facilities. Recently, municipalities have required developers both to finance and construct new residences that are distinctly nonpublic. Two cities, San Francisco and Boston, have adopted programs that link the right to construct new commercial space to the construction or financing of new housing, on the theory that the construction of new office buildings generates a need for housing.

The San Francisco Office Housing Production Program (OHPP) imposes on developers of office projects exceeding 50,000 square feet of office space a concurrent obligation to provide for the development of housing. ${ }^{116}$ This requirement is imposed to offset the increased housing demand that office development presumably would generate. In order to calculate the housing demand generated by new office development, city planners made the following assumptions: forty percent of new workers will seek housing in San Francisco, a typical worker occupies 250 square feet of office space, and one residential dwelling unit houses 1.8 persons. Using these assumptions, the planners determined the number of new residential units required by an office development by dividing the gross square feet of office space by 250 square feet per employee and multiplying that result by .22 (which is .4 employees divided by 1.8 persons per residential unit). ${ }^{117}$ Thus, the developer of a 300,000 square foot office building would be required to provide 264 new residential units. The developer can satisfy the linked housing requirement in one of three ways. He can directly construct or restore the housing himself, he can provide financial aid to a developer for the construction of housing that could not be built without the assistance, or he can invest $\$ 6,000$ per required housing unit for a period of at least thirty years in the city's shared appreciation mortgage revenue bond program. ${ }^{18}$

The San Francisco program is designed to provide housing for persons of low or moderate income and to encourage the construction of housing units with multiple bedrooms. Each bedroom in a dwelling unit counts as one housing unit. Therefore, by constructing units with more than one bedroom, the developer can earn additional housing credits. For example, constructing a three-bedroom apartment would earn him three housing credits. Additional credits are available for constructing affordable housing units for rental or sale to low- or moderate-income households or persons. Two housing credits are awarded for each affordable housing unit developed for rental or sale that is assisted by governmental rental or operating subsidies. If the developer is

116. San Francisco, Cal., Ordinance 358-85 (Aug. 18, 1985); see Share \& Diamond, San Francisco's Office-Housing Production Program, Land Use \& Zoninc Dig., Oct. 1983, at 4, 5.

117. See Share \& Diamond, supra note 116 , at 5 .

118. San Francisco, Cal., Ordinance 358-85, § 2(e)-(g) (Aug. 18, 1985); Share \& Diamond, supra note 116 , at 5 . 
unassisted by rental or operating subsidies, he receives three housing credits for building affordable housing units for moderate-income households and four credits for building affordable housing units for low-income households. In each instance, the developer must guarantee the availability of those housing units to low- or moderate-income residents for at least twenty years. ${ }^{119}$ Thus, in a hypothetical example, a developer could reduce a linkage obligation of 264 housing units to eighty-eight by building only threebedroom apartments. If all of those apartments were available to low-income persons, the developer could reduce his linkage obligation to twenty-two dwelling units.

Initially, the city relied on the California Environmental Quality Act (CEQA) ${ }^{120}$ as the authority for adoption of the Office Housing Production Program. As Share and Diamond have noted:

This state statute allows a city to require mitigation of a project's significant environmental effects. Private projects subject to local discretionary approval, such as downtown office buildings, must meet the CEQA requirements. The city reasoned that new office buildings attract new worker-residents to San Francisco, thereby exacerbating its existing housing shortage. Consequently, the city argued, new office buildings have an impact on the social environment that office developers must mitigate by contributing to the production of housing. ${ }^{121}$

In 1981, the California State Legislature explicitly scotched this theory by amending CEQA to limit the scope of mitigable impacts to those affecting the physical environment. ${ }^{122}$ Since then, San Francisco has relied solely upon the discretionary power of the City Planning Commission to grant or deny permits for large-scale projects as the source of authority for the OHPP exaction. ${ }^{123}$

The Boston linkage program is somewhat different. ${ }^{124}$ It does not require payment or commitment of the entire exaction as a precondition to project approval. Nor does it require the developer of office space to construct lowincome housing. Instead, it provides him with extended payment and construction alternatives.

The Boston linkage requirement was adopted as an addition to the zoning ordinance. ${ }^{125}$ As amended, the ordinance provides that any building or structure having a gross floor area of more than 100,000 square feet, or that will be enlarged enough to exceed 100,000 square feet, is designated as a "development impact project."126 An applicant seeking approval of a

119. San Francisco, Cal., Ordinance 358-85, § 2(e)(1) (Aug. 18, 1985); Share \& Diamond, supra note 116 , at 5 .

120. Cal. Pub. Res. Code $\S \S 21000-21176$ (West 1986).

121. Share \& Diamond, supra note 116 , at 6 .

122. 1981 Cal. Stat. 1352 (codified as amended at Cal. Pub. Res. Code $\$ 21151$ (West 1986)).

123. Share \& Diamond, supra note 116 , at 6 .

124. Boston, Mass., Zoning Code art. 26 (1983), amended by Boston, Mass., Zoning Code art. 26A (1986). A mayoral task force proposal on which article 26 was substantially modeled is described in Advisory Group, Linkage Between Downtown Development and Neighborhood HOUSING: RePORT TO THE MAYOR 12-20 (1983).

125. Article 26 became effective on December 29, 1983. Subsequent amendments to the ordinance, embodied in article 26A, became effective on February 27, 1986.

126. Boston, Mass., Zoning Code art. 26A, \& 2(1) (1986). 
development impact project may make a housing payment exaction of five dollars for each square foot of gross floor area in excess of 100,000 square feet. ${ }^{127}$ The developer must make this payment to a Neighborhood Housing Trust in seven equal annual installments with the first installment due upon issuance of the building permit, followed by six payments due annually thereafter. ${ }^{128}$ The funds paid into the Neighborhood Housing Trust will be used for construction of low- and moderate-income housing units. Alternatively, the developer can comply with the housing payment exaction by "creating or causing to be created" low- and moderate-income housing units at a cost at least equal to that of the housing payment exaction. ${ }^{129}$

The distinctive feature of the Boston program is that the zoning process is used to trigger the requirement for development impact payments. The ordinance requires that persons applying for a variance, a conditional use permit, an exception, or a zoning map or text amendment pursuant to a development impact project plan must also enter into an agreement with the Boston Redevelopment Authority and the Neighborhood Housing Trust to pay the development impact project exaction. ${ }^{130}$ By defining all construction or expansion of buildings or structures in excess of 100,000 square feet as development impact projects, the ordinance sweeps all such development into the category of projects requiring payment of an impact fee.

The Boston linkage program was in place for eighteen months before the first judicial challenge to it was filed. ${ }^{131}$ That challenge did not come from a developer unwilling to pay the housing payment exaction. Instead, a Boston developer challenged a zoning approval given to Massachusetts General Hospital for a long-range hospital expansion program on the ground that the linkage payments biased the zoning process in favor of developers who could make higher payments to the Neighborhood Housing Trust. ${ }^{132}$

A Chicago mayoral task force has recommended the creation of a "linked development fund" that would provide financial assistance to private efforts for residential, commercial, and industrial development in Chicago's neighborhoods. ${ }^{133}$ Among several proposed sources of revenue for the program is a ten dollar per square foot exaction fee on all developments of more than 50,000 square feet. The fee would be paid in five increments, two dollars per square foot at the time a building permit is issued and the balance

127. Id. $\S 3(2)$.

128. Id. \& 2(3)(b).

129. Id. $\S 2(3)(\mathrm{a})$.

130. Id. \&3.

131. The Boston Globe, June 20, 1985, at 24, col. 1.

132. See id.

133. Advisory Comm. on Linked Dev., Draft Report (June 21, 1985) [hereinafter Draft Report], reported in Chicago Tribune, Aug. 26, 1985, $\S 1$, at 1 , col. 8 . The task force recommendation was not unanimous. Five members filed a vigorous minority report, and the task force proposal, which was apparently leaked prematurely, has sparked considerable public controversy. See Chicago Tribune, Aug. 26, 1985, § 1, at 1, col. 8; id. Sept. $2,1985, \S 4$, at 3, col. 1 . The proposed plan also included recommendations for an annual ten cent per square foot "use tax" on all office and commercial space and voluntary development payments into the "linked development fund" to secure increased floor area ratios. 
in four equal annual installments after issuance of an occupancy certificate. ${ }^{134}$ Thus, the developer of a 1 million square foot office tower would pay $\$ 2$ million when he applied for a building permit and an additional $\$ 8$ million in each of the first four years after the building is completed. The funds collected would be used "to generate neighborhood-based jobs; improve, conserve or increase the city's housing stock available to low and moderate income residents; and improve and expand the city's economic base."135

As proposed, the Chicago plan contains a significant weakness not present in the San Francisco and the Boston linkage plans. The Chicago plan is not specifically designed for the construction of new housing, but more for the purpose of neighborhood development, a concept that as yet remains vague. It will be difficult enough to sustain a housing linkage program on the ground that there is a reasonable relationship between the construction of commercial office space and the need for additional housing. It will be even more difficult to demonstrate that connection when the exacted payments are used for a variety of unknown neighborhood development projects. Application of the Illinois specific and uniquely attributable test ${ }^{136}$ to linkage programs would exacerbate the difficulty.

\section{VII}

\section{CONCLUSION}

The reach of subdivision exactions has significantly expanded over the years. What began as a means for preventing a subdivision from shifting to the municipality the responsibility for installing public improvements has been transmuted into a device by which municipalities are shifting to private land developers the cost of facilities and social programs for the general public that local government can no longer afford. ${ }^{137}$ And what was originally a method of guaranteeing installation of physical improvements prior to, or contemporaneously with, the development of land has become a system for accumulating a municipal kitty with which to construct public facilities in the

134. Draft Report, supra note 133, at 17.

135. Id. at 7 .

136. See Pioneer Trust \& Sav. Bank v. Village of Mount Prospect, 22 Ill. 2d 375, 380, 176 N.E.2d 799, 802 (1961); see supra text accompanying notes 49-51.

137. The ever broadening use of development exactions is not a strictly American phenomenon. It has become a commonplace feature of applications for development permission under the British Town and Country Planning Act, 1971, ch. 78. And there, as here, local governmental authorities have frequently overstepped reasonably defensible boundaries.

[T] he town planning justification for some of the more extreme examples of community benefits such, for example, as the provision, or the financing, of municipal housing or community centres which have no real connection with the development proposed or with the development site-is not so clear. This is because, in the examples just quoted, the developer is being asked to provide facilities which it is the local authority's statutory duty to provide themselves and, in addition, because the scale of the community-benefit provision which is being required of the developer is frequently assessed mainly, if not exclusively, by reference to the estimated profitability of the completed scheme. Thus, in such cases, the local planning authority are [sic] revealed as an authority more anxious to find themselves participating in the expected profits of the development than an authority found to be applying appropriate planning policies to the proposed development in a straightforward way. 
future. It is no longer the case that exaction requirements are imposed only when direct benefit to the land and extra costs to government created by development are demonstrable. Instead, exaction fees have approached what the Collis court called "grand theft,"138 as the benefit to private landowners has become marginal, or in some cases, nonexistent, and the public need attributable to new development more tenuous and theoretical. ${ }^{139}$

The decisions with respect to land development exactions have proceeded step by step. No individual decision has represented a remarkable extension of prior law. But few reviewing courts have looked further back than the most recent precedent. Rarely, if ever, has a court stopped to reconsider fundamental constitutional and equitable issues presented by the latest innovation in exactions. If the leap from the most recent precedent is not too great, the courts have been willing to make it. Thus, the law has developed, albeit in relatively small increments, all the way from mandatory construction of on-site physical improvements to compulsory linkage payments. Not even the boldest partisan of the Ayres decision ${ }^{140}$ could have foreseen such a progression.

Heap \& Ward, Planning Bargaining-The Pros and Cons: or, How Much Can the System Stand?, $1980 \mathrm{~J}$. Plan. \& Env't L. 631, 632, reprinted in Heap, The British Experience, Law \& ContemP. Probs., Winter 1987, at 31 app. A.

The debate in England prompted a study by the Department of the Environment of development exactions. See Property Advisory Group, Department of Env't, Planning Gain (1981). The Department of the Environment also published guidelines for local planning authorities to use in imposing planning gain obligations on a development. DeP't of Env't, Circular No. 22/83 (1983), reprinted in Heap, The British Experience, Law \& Contemp. Probs., Winter 1987, at 31 app. B. The Department defines "planning gain" as the imposition on a developer of "an obligation to carry out works not included in the development for which permission has been sought or to make some payment or confer some extraneous right or benefit in return for permitting development to take place." Id. at para. 2. The guidelines permit the developer to impose planning gain obligations when what is required:

(1) is needed to enable the development to go ahead, such as adequate access, water supply, sewerage, drainage and so forth; or,

(2) in the case of financial payments, will contribute to the cost of providing such facilities in the near future; or,

(3) is so directly related to the proposed development and to the use of the land after the development is completed that the development ought not to be permitted without it, such as providing off-street parking or reasonable amounts of open space; or,

(4) in the case of mixed development, is designed to secure an acceptable balance of uses.

(5) The extent of what is required must be fairly and reasonably related in scale and in kind to the benefit which the proposed development will derive from the facilities to be provided.

(6) What the developer is asked to provide, or to finance, must be directly related to the development in question or the use of land after development. As an example, the guidelines indicate that normally it would not be reasonable to seek a contribution for road construction or improvements in the immediate vicinity of a proposed development unless the need arises wholly and substantially from the new development.

Id. at para. 6. For an excellent recent discussion of planning gain exactions in England, see Callies, Developers Agreements and Planning Gain, 17 URB. LAw. 599 (1985).

138. Collis v. City of Bloomington, 310 Minn. 5, 17, 246 N.W.2d 19, 26 (1976).

139. See, e.g., Grupe v. California Coastal Comm'n, 166 Cal. App. 3d 148, 212 Cal. Rptr. 578

(1985). For a discussion of the Grupe decision, see supra text accompanying note 46-48.

140. 34 Cal. 2d 31, 207 P.2d 1 (1949). For a discussion of the Ayres decision, see supra text accompanying notes $16-17$. 
It is time for local governments to realize that the exaction "party" is over. The end is near, not because of the courts, but because of a changing economy. In the post-World War II era, an abundance of cheap land, an extraordinary demand for housing, and the consequent suburban sprawl brought about an influx of housing into previously undeveloped or underdeveloped suburbs that required the construction of substantial amounts of physical infrastructure. The combination of low cost land, high housing demand, and demonstrable public need made subdivision exactions tolerable. Now, however, as the newer suburbs compete for glamorous developments, age overtakes the older suburbs, urban neighborhoods deteriorate and regentrify, and commerce abandons the central city for landscaped office parks, the leverage of local government over development will decrease. Rehabilitation and redevelopment of urban and older suburban areas is unlikely to take place if it is burdened with exactions that represent a disguised and nonuniform system of taxation. In sum, it is time to work toward a consensus between the public and private sectors on which public facility costs a private developer can reasonably be expected to bear. 